Article

\title{
The Differential Composition of Whey Proteomes in Hu Sheep Colostrum and Milk during Different Lactation Periods
}

\author{
Xueying Zhang ${ }^{1}{ }^{(}$, Xinxin Liu $^{1}$, Fadi Li $^{1,2}$ and Xiangpeng Yue ${ }^{1, *}$ \\ 1 State Key Laboratory of Grassland Agro-Ecosystems, Key Laboratory of Grassland Livestock \\ Industry Innovation, Ministry of Agriculture and Rural Affairs, Engineering Research Center \\ of Grassland Industry, Ministry of Education, College of Pastoral Agriculture Science and Technology, \\ Lanzhou University, Lanzhou 730020, China; zhangxy19@lzu.edu.cn (X.Z.); liuxx2013@lzu.edu.cn (X.L.); \\ lifd@lzu.edu.cn (F.L.) \\ 2 Engineering Laboratory of Sheep Breeding and Reproduction Biotechnology in Gansu Province, \\ Minqin 733300, China \\ * Correspondence: lexp@lzu.edu.cn
}

Received: 16 September 2020; Accepted: 22 September 2020; Published: 1 October 2020

Simple Summary: To reveal the temporal variation of ovine whey protein after lambing and provide basic data for lamb feeding and feed product development, the differential proteomes of whey during the transition from colostrum to mature milk in Hu sheep were studied. A total of 52 differentially expressed protein spots were detected among milk samples from six time points after lambing, identifying 25 differentially expressed proteins. Gene ontology (GO) annotation and Kyoto Encyclopedia of Genes and Genomes (KEGG) pathway analysis revealed the differentially expressed proteins involved in multiple biological functions, especially in immunity. Most of the differential proteins were highly expressed in the first $7 \mathrm{~d}$ after lambing, and the expression level decreased to a minimum value at $56 \mathrm{~d}$.

\begin{abstract}
Colostrum and milk proteins are essential resources for the growth and development of the newborns, while their kinds and amounts vary greatly during the lactation period. This study was conducted to better understand whey proteome and its changes at six lactation time points $(0 \mathrm{~d}, 3 \mathrm{~d}$, $7 \mathrm{~d}, 14 \mathrm{~d}, 28 \mathrm{~d}$, and $56 \mathrm{~d}$ after lambing) in Hu sheep. Using two-dimensional gel electrophoresis (2-DE) and matrix-assisted laser desorption/ionization time-of-flight mass spectrometry (MALDI TOF/TOF MS) technologies, a total of 52 differentially expressed protein spots (DEPS), corresponding to 25 differentially expressed proteins (DEPs), were obtained. The protein spots abundance analysis revealed that the proteins are the most abundant at $0 \mathrm{~d}$ after lambing. Gene ontology (GO) annotation and Kyoto Encyclopedia of Genes and Genomes (KEGG) pathway analysis were used to explore the biological functions of the DEPs. The biological process was mainly involved in localization, the single-organism process, the cellular process, and a series of immune processes. The cellular components engaged in the extracellular region were the cell, organelle, and membrane. The most prevalent molecular function was binding activity. In addition, the DEPs were involved in nine significant pathways, including the Hippo signaling pathway and Complement and coagulation cascades. These results intuitively presented the changes in Hu sheep whey proteins during a 56-d lactation period, and revealed potential biological functions of the DEPs, providing a scientific basis for early weaning.
\end{abstract}

Keywords: Hu sheep; whey protein; 2-DE; MALDI TOF/TOF; MS/MS 


\section{Introduction}

Colostrum and mature milk are optimal sources of nutrients and bioactive factors for newborn lambs before weaning [1]. Milk proteins are essential molecules in the milk functional components. They can be divided into three major groups: caseins (CNs), whey proteins, and milk fat globule membrane proteins (MFGMPs) [2]. These proteins can be separated by centrifugation [3], and current research shows that they have different functions. CNs are the main nutritional proteins in milk, providing essential amino acids for the newborns [4]. MFGMPs are involved in fat and protein transport, cell signal transduction, metabolic regulation, and other biological processes [5,6]. Whey proteins, accounting for about $20 \%$ of the total milk proteins [3], provide essential protection for neonates, including antioxidant activities, immune-stimulating responses, anti-inflammation activities, and so on [2]. Because of the vital physiological functions, the bioactive proteins included in whey have received much attention in recent years.

Besides high-abundance proteins, there are various of low-abundance proteins in whey which have biological functions in the development and immunity of lambs [7]. Previous studies of whey proteomes have focused on the difference among different species. Yang et al. analyzed the whey protein expression patterns of cow, yak, buffalo, goat, and camel, and a series of species-specific proteins were identified [8]. Similar comparative research was reported by El-Hatmi et al., showing that human and camel whey lacks $\beta-\mathrm{Lg}$, which is a major protein in the whey of other species [9]. Because of the different requirements for infants' growth and development after birth, the kinds and amounts of whey proteins vary greatly at different lactation stages. Especially in the colostrum, whey proteins are more abundant and thus provide extra natural defense for the newborns [10]. Studies on whey proteomes at different stages of lactation have been carried out for decades. Of these, most studies focused on human [11], bovine [12], yak [13], and goat milk [14], while the dynamic changes in sheep proteomes during the early lactation period is still unclear. The Hu sheep is an excellent sheep breed in China, which is recognized for its high prolificacy, early sexual maturity and year-round estrus. Although the Hu sheep has a high prolificacy characteristic, the low survival rate of lambs is the key factor restricting the industrial development [15]. Therefore, analyzing the changes in Hu sheep whey proteins during different lactation stages can help to ensure the intake of function proteins and determine the time of early weaning, which is of great significant for improving the survival rate and promoting early development of lambs.

Two-dimensional electrophoresis (2-DE) technology can efficiently separate proteins from complex systems, and, coupled with mass spectrometry (MS), it is a common method to characterize animal proteomics [3]. The objective of this research was to explore changes in the whey proteome in Hu sheep at six time points after lambing, using 2-DE coupled with MALDI-TOF MS. We then further analyzed the biological functions of the differentially expressed proteins by gene ontology (GO) annotations and the Kyoto Encyclopedia of Genes and Genomes (KEGG) analysis. This is the first study to explore the differential proteomics of $\mathrm{Hu}$ sheep during a lamb's postnatal development, and the results provide scientific data for early weaning and feed product development.

\section{Materials and Methods}

All experimental procedures were carried out following the experimental field management protocols (file No: 2010-1 and 2010-2) approved by Lanzhou University. All efforts were taken to minimize animal suffering.

\subsection{Animals and Preparing of Whey Fractions}

Multiparous Hu sheep were from Zhongtian sheep Ltd. (Jinchang City, Gansu Province, China). Referenced to Fragkou et al., diagnosis of clinical mastitis was based on findings of the clinical examination (swollen and painful udder, abnormal milk, high rectal temperature, lameness on the side of the affected gland); diagnosis of subclinical mastitis was depended on the somatic cell counts in ewes' milk: the cell counts $<0.5 \times 10^{6}$ or $>1.0 \times 10^{6}$ cells $\mathrm{mL}^{-1}$ indicate absence or presence of 
subclinical mastitis, respectively, and when cell counts are within this rage, a bacteriological examination of milk is required for confirmation of subclinical mastitis [16]. A tiger red plate agglutination test was conducted to detect brucellosis; the collected serum was bound to the antigen on the plate, and no visible agglutination reaction occurring within 4 min was deemed as a healthy individual. Finally, six healthy sheep were selected and reared at the same condition and fed by the same feed. All of the ewes were at the second parity with a litter size of two. The fresh milk samples were individually collected from the six sheep at 08:00-09:00 on $3 \mathrm{~d}, 7 \mathrm{~d}, 14 \mathrm{~d}, 28 \mathrm{~d}, 56 \mathrm{~d}$ and $4 \sim 5 \mathrm{~h}(0 \mathrm{~d})$ after lambing by a manual milking manner. A total of 36 milk samples, approximately $10 \mathrm{~mL}$ for each ewe, were collected and immediately frozen at $-20{ }^{\circ} \mathrm{C}$ until whey preparation.

Milk samples with equal volume of $1 \mathrm{~mL}$ from six ewes at the same time point were pooled together and mixed thoroughly by vortexing for $3 \mathrm{~min}$, giving a representative whey sample for each time point during the lactation. Subsequently, the six mixed milk samples were defatted by centrifugation at $3000 \times g$ and $4{ }^{\circ} \mathrm{C}$ for $15 \mathrm{~min}$ (Biofuge Stratos, Heraeus, Hanau, Germany). The precipitated casein was further removed by ultracentrifugation at $100,000 \times g$ and $4{ }^{\circ} \mathrm{C}$ for $60 \mathrm{~min}$ (CS120GXL, Hitachi, Chiyoda $\mathrm{Ku}$, Tokyo, Japan) to obtain the whey fraction [8,17]. The protein concentration of prepared whey was determined by bicinchoninic acid (BCA) Protein Assay Kit (PC0020, Solarbio Ltd., Beijing, China) according to the manufacturer's instructions with bovine serum albumin (BSA) as a standard for calibration curve. The six whey samples were finally stored at $-80^{\circ} \mathrm{C}$ prior to 2 -DE analysis.

\subsection{Two-Dimensional Gel Electrophoresis}

A total of $250 \mu \mathrm{g}$ of whey protein sample was mixed in $350 \mu \mathrm{L}$ of immobilized pH gradient (IPG) rehydration buffer comprising of $7 \mathrm{M}$ urea, $2 \mathrm{M}$ thiourea, 4\% (w/v) 3-[(3-cholamidopropyl)-dimethyl -ammonio]-propanesulphonic acid (CHAPS), 0.5\% (v/v) pH 4-7 IPG buffer, $50 \mathrm{mM}$ dithiothreitol (DTT) and $0.25 \%$ bromophenol blue [18]. First, dimensional isoelectric focusing (IEF) was carried out using pH 4-7 NL 17 cm-long IPG strips (Bio-Rad, Hercules, CA, USA) at $20^{\circ} \mathrm{C}$. The IPG strips were swelled overnight and passive rehydrated at $50 \mathrm{~V}$ for $10 \mathrm{~h}$, and then IEF was performed at $20^{\circ} \mathrm{C}$ by a series of increasing voltage steps as follows: $2 \mathrm{~h}$ at $250 \mathrm{~V} ; 1 \mathrm{~h}$ at $1000 \mathrm{~V} ; 6 \mathrm{~h}$ at $9000 \mathrm{~V} ; 90,000$ voltage hours at $9000 \mathrm{~V}$ [18].

After the first dimension, IPG strips were equilibrated for 12 min under gentle stirring with a solution containing 2\% $(w / v)$ dithiothreitol, $0.375 \mathrm{M}$ Tris- $\mathrm{HCl} \mathrm{pH} 8.8,6 \mathrm{M}$ urea, 20\% (v/v) glycerol, and $2 \%(w / v)$ sodium dodecyl sulphate (SDS) at room temperature, and following incubation with a solution composed of $2.5 \%(w / v)$ iodoacetamide, $0.375 \mathrm{M}$ Tris- $\mathrm{HCl} \mathrm{pH} 8.8,6 \mathrm{M}$ urea, 20\% (v/v) glycerol, and $2 \%(w / v)$ SDS at room temperature for another $12 \mathrm{~min}$. The second dimension was performed using 12\% SDS-polyacrylamide gel electrophoresis (SDS-PAGE). The IPG strips were put on top of the SDS gels, which were poured up to $1 \mathrm{~cm}$ from the top of the plates and then sealed with $1.5 \mathrm{~mL}$ of a solution containing $0.5 \%$ low melting-point agarose diluted in hot $\left(70{ }^{\circ} \mathrm{C}\right)$ SDS running buffer (25 mM Tris- $\mathrm{HCl}$ pH 8.3, $192 \mathrm{mM}$ glycine, 0.1\% SDS) [19]. In the second dimension electrophoresis, the gels were run under circulating water bath conditions at $50 \mathrm{~V}$ for $1 \mathrm{~h}$, and then at $200 \mathrm{~V}$ until the bromophenol blue indicator came out of the gels. The 2-DE for each sample was run in duplicate to assure the reproducibility of the result.

\subsection{Analysis of Gel Images and Protein Spots Abundance}

After electrophoresis, analytical gels were stained with Coomassie Brilliant Blue G-250 solution [20]. High-resolution gel images (600 dpi) were obtained using an image scanner (model PowerLook 2100XL ImageScanner, UMAX Technologies, Atlanta, GA, USA) and were analyzed by using PDQuest 8.0 software (Bio-Rad, Hercules, CA, USA). The analysis of images included spot detection, background subtraction, pI/Mw calibration, spot normalization, gel matching, and statistics analysis. The quantity of each spot on the gel images was normalized by total valid spot intensity, and the relative volume of protein spot was calculated and considered as its expression level. Spot intensity was compared 
between six gel images, and the variation over 2-fold in the relative percent volume as differentially expressed protein spots (DEPS) was chosen. This DEPS were selected for further protein identification.

\subsection{In-Gel Digestion and Mass Spectrometric Analysis}

The DEPS were excised manually from the gels, and gel pieces were destained with 200-400 $\mu \mathrm{L}$ of $30 \%(w / v)$ acetonitrile (ACN) in $0.1 \mathrm{M}$ ammonium bicarbonate. Afterwards, the destained gel pieces were dried completely by vacuum centrifugation at $200 \times \mathrm{g}$ for $30 \mathrm{~min}$ under room temperature (Eppendorf Concentrator Plus, Hamburg, Germany). Subsequently, each dry gel piece was incubated at $37^{\circ} \mathrm{C}$ overnight with $5 \mu \mathrm{L}$ of $5 \mathrm{ng} / \mu \mathrm{L}$ sequence-grade trypsin (Promega, Madison, WI, USA). The digested peptides were extracted 3 times at $37^{\circ} \mathrm{C}$ by $8 \mu \mathrm{L}$ aliquots of $5 \%(v / v)$ trifluoroacetic acid (TFA) for $1 \mathrm{~h}$, $2.5 \%(v / v)$ TFA in $50 \%(v / v)$ ACN for $1 \mathrm{~h}$, and $100 \%(v / v)$ ACN for $1 \mathrm{~h}$. The peptide solution was then dried in a vacuum centrifugation ( $200 \times g, 3 \mathrm{~h}$, room temperature) and re-solubilized in $2 \mu \mathrm{L}$ of $0.5 \%$ $(v / v)$ TFA for MS analysis [19].

MS and MS/MS data for protein identification were obtained using a MALDI-TOF-TOF instrument (4800 proteomics analyzer; Applied Biosystems, Forster City, CA, USA). Instrument parameters were set using the 4000 Series Explorer software (Applied Biosystems, Forster City, CA, USA). The MS spectra were recorded in reflector mode in a mass range from 800 to 4000 with a focus mass of 2000. MS was used a CalMix5 standard to calibrate the instrument (ABI 4700 Calibration Mixture). For one main MS spectrum, 25 subspectra with 125 shots per subspectrum were accumulated using a random search pattern. For MS calibration, autolysis peaks of trypsin $([M+H]+842.5100$ and 2, 211.1046) were used as internal calibrates, and up to 10 of the most intense ion signals were selected as precursors for MS/MS acquisition, excluding the trypsin autolysis peaks and the matrix ion signals. In MS/MS positive ion mode, for one main MS spectrum, 50 subspectra with 50 shots per subspectrum were accumulated using a random search pattern. Collision energy was $2 \mathrm{kV}$, collision gas was air, and default calibration was set using the Glu1-Fibrino-peptide B $([\mathrm{M}+\mathrm{H}]+1570.6696)$ spotted onto Cal 7 positions of the MALDI target.

\subsection{Protein Identification}

Combined peptide mass fingerprinting PMF and MS/MS queries were performed using the MASCOT search engine 2.2 (Matrix Science, Boston, MA, USA) embedded into GPS-Explorer Software 3.6 (Applied Biosystems, Forster City, CA, USA) on the Swiss Uniport database and NCBI database with the following parameter settings: 100 ppm mass accuracy, trypsin cleavage, one missed cleavage allowed, carbamidomethylation set as fixed modification, oxidation of methionine was allowed as variable modification, and MS/MS fragment tolerance was set to $0.4 \mathrm{Da}$.

\subsection{Bioinformatic Analysis}

The fasta sequences of the identified differentially expressed proteins (DEPs) were extracted from UniProtKB database (Release 2019_10) based on these protein identifiers. Then the retrieved sequences were locally searched against SwissPort database (mammal) using the NCBI BLAST+ client software (ncbi-blast-2.2.28+-win32.exe) to find homologue sequences from which the functional annotation can be transferred to the studied sequences. In this work, the top 10 blast hits with E-value less than $1 \times 10^{-3}$ for each query sequence were retrieved and loaded into Blast2GO [21] (Version 2.8.0) for GO [22] mapping and annotation. In this work, an annotation configuration with an E-value filter of $1 \times 10^{-6}$, default gradual EC weights, a GO weight of 5 , and an annotation cutoff of 55 were chosen. Un-annotated sequences were then re-annotated with more permissive parameters. The sequences without BLAST hits and un-annotated sequences were then selected to go through an InterProScan against EBI databases to retrieve functional annotations of protein motifs and merge the InterProScan $\mathrm{GO}$ terms to the annotation set. Following annotation and annotation augmentation steps, the studied proteins were blasted against KEGG GENES (mammal) to retrieve their KOs and were subsequently mapped to pathways in KEGG [23]. 


\section{Results and Discussion}

\subsection{The Analysis of Two-Dimensional Electrophoresis Maps}

This study used 2-DE to analyze the differential proteome of Hu sheep whey at $0 \mathrm{~d}, 3 \mathrm{~d}, 7 \mathrm{~d}, 14 \mathrm{~d}$, $28 \mathrm{~d}$, and $56 \mathrm{~d}$ after lambing, detecting 64, 53, 49, 61, 41, and 57 protein spots, respectively. The 2-DE maps of each time points are shown in Figure S1. To verify the reliability and reproducibility of the identification results, a technical repeat of each sample was conducted under the same electrophoresis condition. The matching rates of protein spots between two 2-DE for the same sample were $100 \%$, $100 \%, 95 \%, 96 \%, 97 \%$, and $96 \%$ for six time points, respectively, indicating a high reproducibility and accuracy of the protein spots. The PDQuest 8.0 software was used to qualify the density of the protein spots, and thus identify the DEPS.

As a result of the comparisons, a total of 52 DEPS were determined among the samples from the six time points, and their localization in maps is shown in Figure 1. The expression abundances of the DEPS are summarized in Table 1. A total of 43 DEPS were identified on D 0 compared with the D 3 group, including 19 DEPS unique to D 0, one unique to D 3, and three upregulated and 20 downregulated in D 3. Distribution of the DEPS between D 3 and D 7 showed that 11 DEPS were only present in D 3, 13 were unique to D 7, and eight were upregulated and two downregulated in D 7. Together, these amount to 34 DEPS between D 3 and D 7. Fewer DEPS were detected between D 7 and D 14. These included one protein spot unique to D 7, six unique to D 14, and five upregulated and 14 downregulated DEPS in D 14. The amounts of DEPS were increased in the comparison between D 14 and D 28; a total of 31 DEPS were detected. Finally, the amounts of DEPS were the lowest in the comparison between D 28 and D 56-only 20 DEPS were identified. The comparison of DEPS amounts between the two adjacent time points revealed that the proteins have the greatest difference between $0 \mathrm{~d}$ and $3 \mathrm{~d}$ after lambing, and the amounts of DEPS decreased gradually. This might be closely related to the abundant function of colostrum [24].

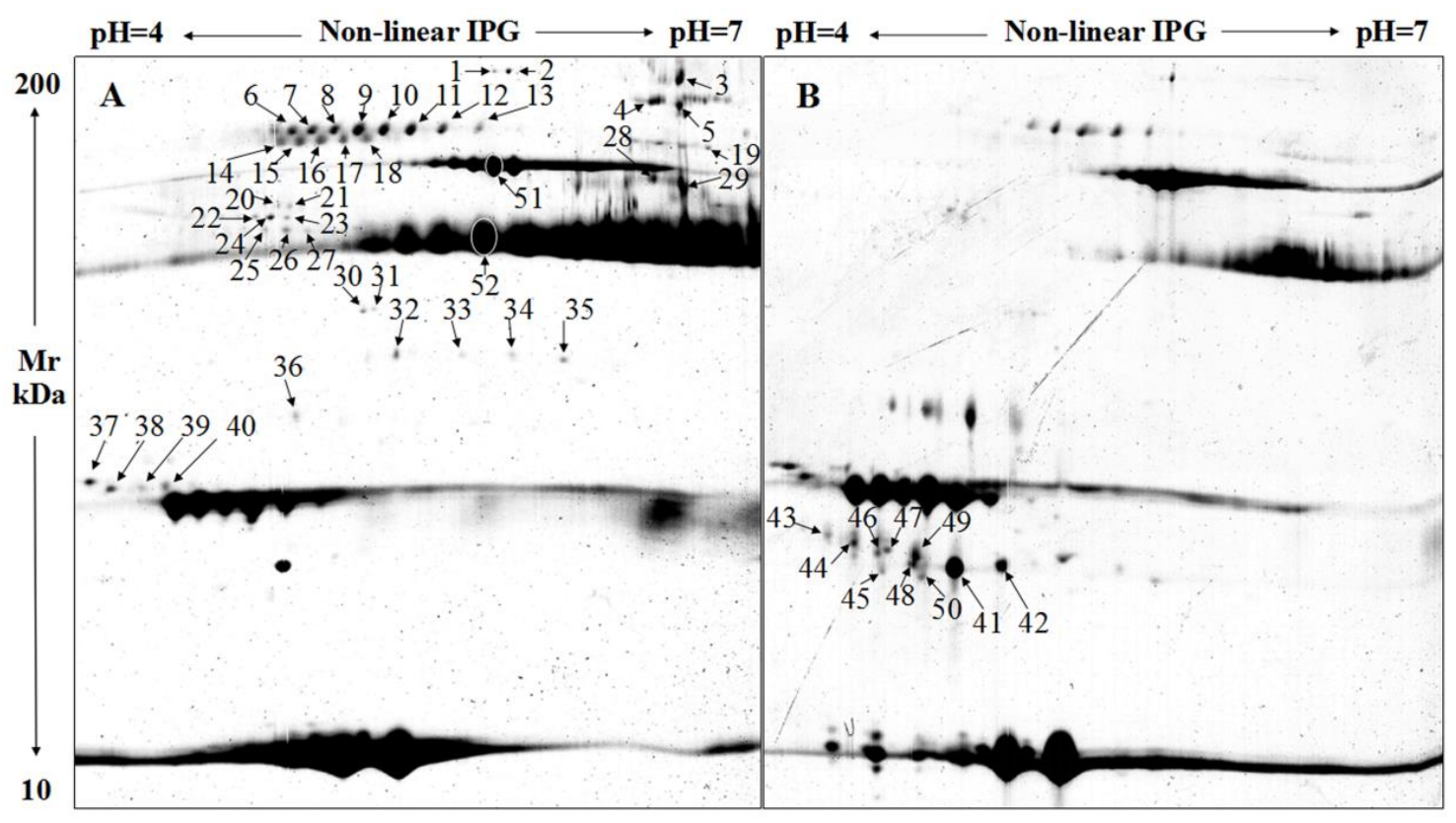

Figure 1. Localization of the identified differentially expressed protein spots (DEPS) in two-dimensional gel electrophoresis (2-DE) maps. (A): 2-DE maps of D 0; (B): 2-DE maps of D 7. 
Table 1. The expression abundance of 52 DEPS.

\begin{tabular}{|c|c|c|c|c|c|c|}
\hline Spot Number & D 0 & D 3 & D 7 & D 14 & D 28 & D 56 \\
\hline 1 & 256 & 156 & 0 & 100 & 2943 & 111 \\
\hline 2 & 539 & 140 & 5297 & 135 & 2558 & 136 \\
\hline 3 & 59,805 & 0 & 0 & 0 & 0 & 0 \\
\hline 4 & 9070 & 0 & 0 & 0 & 0 & 0 \\
\hline 5 & 9570 & 0 & 0 & 0 & 0 & 0 \\
\hline 6 & 3908 & 156 & 0 & 0 & 0 & 0 \\
\hline 7 & 12,886 & 107 & 0 & 125 & 644 & 0 \\
\hline 8 & 6720 & 297 & 108 & 98 & 3495 & 102 \\
\hline 9 & 15,387 & 393 & 3186 & 124 & 8728 & 137 \\
\hline 10 & 10,252 & 732,945 & 6554 & 136 & 5530 & 0 \\
\hline 11 & 9745 & 525 & 7490 & 153 & 8517 & 0 \\
\hline 12 & 8298 & 136 & 8633 & 129 & 10,124 & 163 \\
\hline 13 & 4143 & 0 & 2753 & 158 & 2659 & 0 \\
\hline 14 & 10,893 & 139 & 0 & 0 & 0 & 0 \\
\hline 15 & 13,823 & 223 & 0 & 0 & 0 & 0 \\
\hline 16 & 12,456 & 144 & 0 & 0 & 0 & 0 \\
\hline 17 & 8233 & 73 & 0 & 0 & 0 & 0 \\
\hline 18 & 10,884 & 12 & 0 & 0 & 0 & 0 \\
\hline 19 & 1450 & 222 & 0 & 110 & 1047 & 0 \\
\hline 20 & 234 & 0 & 0 & 0 & 0 & 0 \\
\hline 21 & 260 & 0 & 0 & 0 & 0 & 0 \\
\hline 22 & 214 & 0 & 0 & 0 & 0 & 0 \\
\hline 23 & 259 & 0 & 0 & 0 & 0 & 0 \\
\hline 24 & 3597 & 45 & 1213 & 100 & 2992 & 0 \\
\hline 25 & 1075 & 0 & 440 & 160 & 1233 & 0 \\
\hline 26 & 1110 & 0 & 0 & 140 & 117 & 0 \\
\hline 27 & 580 & 52 & 0 & 100 & 0 & 0 \\
\hline 28 & 8724 & 0 & 0 & 0 & 1725 & 0 \\
\hline 29 & 6494 & 0 & 0 & 0 & 2521 & 0 \\
\hline 30 & 1152 & 0 & 633 & 112 & 0 & 0 \\
\hline 31 & 390 & 0 & 0 & 0 & 0 & 0 \\
\hline 32 & 3299 & 0 & 238 & 0 & 0 & 0 \\
\hline 33 & 597 & 0 & 0 & 0 & 0 & 0 \\
\hline 34 & 838 & 0 & 0 & 0 & 0 & 0 \\
\hline 35 & 1834 & 0 & 0 & 0 & 0 & 0 \\
\hline 36 & 2150 & 0 & 15,751 & 106 & 0 & 0 \\
\hline 37 & 7599 & 321 & 0 & 100 & 0 & 110 \\
\hline 38 & 6208 & 389 & 1046 & 100 & 11,750 & 100 \\
\hline 39 & 3157 & 138 & 13,261 & 150 & 18,076 & 100 \\
\hline 40 & 7160 & 139 & 3152 & 112 & 15,842 & 101 \\
\hline 41 & 3134 & 11,587 & 13,087 & 11,570 & 2499 & 3568 \\
\hline 42 & 0 & 5373 & 4586 & 5541 & 0 & 0 \\
\hline 43 & 0 & 0 & 114 & 300 & 0 & 0 \\
\hline 44 & 0 & 0 & 259 & 820 & 0 & 0 \\
\hline 45 & 0 & 0 & 90 & 190 & 0 & 0 \\
\hline 46 & 0 & 0 & 318 & 870 & 0 & 0 \\
\hline 47 & 0 & 0 & 102 & 406 & 0 & 0 \\
\hline 48 & 0 & 0 & 230 & 116 & 0 & 0 \\
\hline 49 & 0 & 0 & 1125 & 532 & 0 & 0 \\
\hline 50 & 0 & 0 & 283 & 305 & 0 & 0 \\
\hline 51 & 386,070 & $1,207,960$ & 638,265 & 581,040 & 529,120 & 500,480 \\
\hline 52 & $1,190,595$ & 457,725 & 283,400 & 274,480 & 156,200 & 25,240 \\
\hline
\end{tabular}




\subsection{Mass Spectrometry Analysis of Differentially Expressed Protein Spots}

The proteins related to the 52 DEPS mentioned above were identified using MALDI-TOF-MS. The result was that the 52 DEPS were identified as 24 characterized and 1 uncharacterized proteins (Table 2).

In previous study, Pisanu et al. established a 2-DE reference map of whey proteins in Sarda dairy sheep [6], and the image profiles is similar with that of Hu sheep in this study. The main proteins in whey were observed in both breeds. It should be noted that beta-lactoglobulin (LACB) and alpha-lactalbumin (LALBA) were not analyzed in present study, since no significant difference was shown in the level of expression of these proteins during the whole detected process. Researchers have tried to explore the dynamic changes in milk whey proteins during a 90-d lactation period on Santa Ines sheep by SDS-PAGE, but only a few high-abundance proteins were identified, and the variation in the protein expression levels were only reflected in serum albumin and immunoglobulin [25]. It was considered that the method of protein separation was the main impact factor for the identification results. Thus, 2-DE can effectively separate proteins from two dimensions based on the isoelectric point and molecular size. Although there are rapid developments in proteomics technology, 2-DE is still widely used in the study of whey proteome identification [26].

The tendency of change in Hu sheep whey proteins was analyzed based on the point abundance at the different lactation time points. The results showed that the proteins were most abundant in D 0 . At this stage, almost all of the identified differentially expressed proteins were existed, and the proteins performed a high-abundance compared with other time points. In particular, four of these proteins existed only at this stage. These were lactotransferrin (LTF, spots 3, 4, 5), nucleobindin-1 (NUCB-1, spots 20, 21), alpha-1-antitrypsin transcript variant 1 (A1ATV1, spot 23) and G protein-regulated inducer of neurite outgrowth 1 (GPRIN1, spots 34,35). These proteins are essential for the protection and development of newborns. LTF is a key bioactive protein with anti-inflammatory and antimicrobial properties in whey, which is believed to protect the infants against bacterial infection and inflammation [27]. In a previous study, the concentration of LTF was reported to be $5 \mathrm{~g} / \mathrm{L}$ in human colostrum, compared to 2-3 g/L in mature human milk, and $0.8 \mathrm{~g} / \mathrm{L}$ in bovine colostrum, compared to $0.03-0.49 \mathrm{~g} / \mathrm{L}$ in mature bovine milk [27]. These results suggest that LTF is secreted at the early stage of lactation. In addition, the research on the comparison of whey protein between East Friensian Milk sheep and Hu sheep revealed that the abundance of LTF was significantly different among breeds [28]. A1ATV1 is a protease inhibitor and an acute-phase protein [29]. During inflammation, A1ATV1 penetrates the capillary wall, passing into the extracellular matrix, where it has a certain restrictive effect on acute inflammation [29]. NUCB-1 is a calcium-binding protein that participates in energy metabolism. It was shown to be differentially expressed between colostrum and mature milk in sheep [30], yaks [13], and cattle [12], whereas the expression of NUCB-1 was reported to be upregulated in the mature cow milk [12], which is inconsistent with our results. The difference is thought to be arise from the differential requirement for the development of the offspring of different species. GPRIN1 might play a pivotal role in regulating neurite outgrowth by interacting with other neuroproteins [31]. Research on this protein is, however, rather limited. It can be concluded that colostrum at $0 \mathrm{~d}$ after lambing plays vital roles in the health and development of newborns, so adequate colostrum intake at this stage is crucial. A series of immune-related proteins were highly expressed in the first $7 \mathrm{~d}$ after lambing. Immunoglobulin heavy constant mu (IGHM, spots 14, 15, 16, 17, 18) was found to be abundant in D 0 and disappeared by D 7. Complement C3 (C3, spot 32), which is an important part of the immune system that provides a link between the innate and adaptive immune systems [32], was only existent on D 0 and D 7. Another important multifunction protein, clusterin (CLU, spot 36) was highly abundant on D 0 and D 7, and the expression of it showed a dramatic decrease in subsequent time points. As is well known, CLU can promote cell aggregation and regulates reproduction, immunization, lipid transportation, and apoptosis [33], and is essential for lambs' postnatal development. Moreover, a kind of microfilament structural protein, Actin gamma 1 (ACTG1, spots 30, 31), was also highly expressed in first $7 \mathrm{~d}$. The presence of keratin and actin as well as cell support and dynein proteins in the milk indicates that the mammary gland goes through slight alterations during early lactation [34]. According to 
the changes in the above protein abundances, we have found that $7 \mathrm{~d}$ after lambing is a key time point for the transition from colostrum to mature milk.

Ten protein spots were found to be present in whey protein of all time points. Their spot numbers were $2,8,9,12,38,39,40,41,51$, and 52. Among them, spots 38, 39, 40, 41 were identified as casein alpha S1 variant (CSN1S1), casein alpha S2 variant (CSN1S2), casein kappa fragment (CSN3, fragment), and casein kappa (CSN3), respectively. Caseins contain all the essential amino acids, which are the main nutritional source of newborn lambs, and it also promotes the lambs' absorption of calcium and phosphorus from the milk [35]. The caseins identified in present study are the residue from the process of whey protein separation, which is inevitable. Serum albumin (ALB, spot 51) is the main whey protein, which infiltrates from the blood into the mammary gland [12]. Similar to the results on Santa Ines sheep, the expression level of ALB declined gradually after $14 \mathrm{~d}$ postpartum [25], indicating that there was no breed difference in the expression level changes of ALB. The immunoglobulin alpha heavy chain (IGHC, spot 52) is an important immune protein that inhibits the invasion of pathogenic microorganisms [25]. In our study, IGHC was highly expressed in D 0 , and the expression subsequently declined, reaching the lowest level on D 56. Spots 8, 9, 12 were identified as another immune protein, polymeric immunoglobulin receptor (PIGR), which functions in transporting polymeric immunoglobulin across epithelial cells and into external secretion in animals [36]. Mammary gland epithelial cells were found to express this protein [36]. Moreover, protein yippee-like 5 (YPEL5, spot 2) was also expressed at all stages of lactation. The protein is a member of the YPEL family and plays an important role in cell cycle and proliferation [37]. Ha et al. established the largest sheep whey protein database to date [38], but YPEL was no found on it. Considering that the protein database was from the whey of East Friesian sheep, it was believed that the difference in type of proteins was caused by breed differences.

Other important bioactive proteins were also differentially expressed during lactation. Vitamin D-binding protein (VTDB, spots 22, 24) was highly expressed on D $0, D 7$, and D 28, while its expression was low on D 3, and D 14. VTDB has several physiological functions, including participating in the transport of vitamin D and its metabolites and removing actin from tissues [39]. Keratin 10 (KRT10, spots $28,29,33,42$ ) is a major cytoskeletal protein in keratinocytes, and it maintains the integrity and continuity of the epithelial tissue [40]. Airway lactoperoxidase (ALPO, spot 19) is a kind of oxidoreductase that acts along with heme and metal ions [2]. The expression of ALPO in this study was high on D 0 , rapidly decreased on $\mathrm{D} 3$, and reached an undetectable level on D 7. Its level then increased on D 14 and D 28 and then decreased again down to zero on D 56.

Early weaning is an effective way to improve the utilization rate of ewe, which is the key to promote production efficiency of indoor feeding in rural areas [41]. Due to the difference in breed, geography and management, the weaning age has no worldwide conclusions. Rather than dairy goats ( $28 \mathrm{~d})$, meat sheep are usually weaned over $45 \mathrm{~d}$ postpartum. As typical meat aptitude sheep in China, Hu sheep are widely weaned for $56 \mathrm{~d}$ after lambing in industrial farming. While subjected to the effect of changes in the ewe lactation curve, weaning at this time will lag the development of lambs [42]. Recent research also pointed to the notion that weaning $28 \mathrm{~d}$ after lambing could promote gastrointestinal tract development in Hu lambs [43]. In the present study, the abundance of the identified proteins decreased to a minimum level on D 56, and the majority of them even disappeared. This result indicates that weaning $28 \mathrm{~d}$ after lambing is feasible. 
Table 2. List of protein identifications obtained from 2-DE maps of ovine whey.

\begin{tabular}{|c|c|c|c|c|c|c|c|c|c|c|c|}
\hline Spot Number & Protein Name & Abbreviation & Organism & Accession No. & Protein MW & Protein PI & Pep. Count & Protein Score & Protein Score C. I. \% & Total Ion & Total Ion C. I. \% \\
\hline 1 & Globin C, coelomic & GLBC & Ovis aries & tr|W5P5T4 & $103,838.6$ & 5.87 & 17 & 163 & 100 & 121 & 100 \\
\hline 2 & $\begin{array}{c}\text { Protein yippee-like } 5 \\
\text { (Fragment) }\end{array}$ & YPEL5 & Ovis aries & tr|W5QEE0 & $14,933.5$ & 8.45 & 3 & 17 & 0 & & \\
\hline 3 & Lactotransferrin & LTF & Capra hircus & splQ29477 & $79,361.3$ & 6.75 & 21 & 205 & 100 & 158 & 100 \\
\hline 4 & Lactotransferrin & LTF & Capra hircus & $\mathrm{sp} \mid \mathrm{Q} 29477$ & $79,362.3$ & 6.75 & 23 & 319 & 100 & 308 & 100 \\
\hline 5 & Lactotransferrin & LTF & Capra hircus & $\mathrm{sp} \mid \mathrm{Q} 29477$ & $79,363.3$ & 6.75 & 21 & 123 & 100 & 78 & 100 \\
\hline 6 & $\begin{array}{c}\text { Polymeric } \\
\text { immunoglobulin } \\
\text { receptor }\end{array}$ & PIGR & Bos taurus & sp|P81265 & $83,694.6$ & 7.07 & 13 & 154 & 100 & 122 & 100 \\
\hline 7 & $\begin{array}{c}\text { Polymeric } \\
\text { immunoglobulin } \\
\text { receptor }\end{array}$ & PIGR & Bos taurus & sp|P81265 & $83,694.6$ & 7.07 & 14 & 375 & 100 & 337 & 100 \\
\hline 8 & $\begin{array}{l}\text { Polymeric } \\
\text { immunoglobulin } \\
\text { receptor }\end{array}$ & PIGR & Bos taurus & sp|P81265 & $83,694.6$ & 7.07 & 14 & 392 & 100 & 354 & 100 \\
\hline 9 & $\begin{array}{c}\text { Polymeric } \\
\text { immunoglobulin } \\
\text { receptor }\end{array}$ & PIGR & Bos taurus & sp|P81265 & $83,694.6$ & 7.07 & 12 & 387 & 100 & 359 & 100 \\
\hline 10 & $\begin{array}{l}\text { Polymeric } \\
\text { immunoglobulin } \\
\text { receptor }\end{array}$ & PIGR & Bos taurus & sp|P81265 & $83,694.6$ & 7.07 & 16 & 450 & 100 & 401 & 100 \\
\hline 11 & $\begin{array}{c}\text { Polymeric } \\
\text { immunoglobulin } \\
\text { receptor }\end{array}$ & PIGR & Bos taurus & sp|P81265 & $83,694.6$ & 7.07 & 13 & 377 & 100 & 345 & 100 \\
\hline 12 & $\begin{array}{c}\text { Polymeric } \\
\text { immunoglobulin } \\
\text { receptor }\end{array}$ & PIGR & Bos taurus & sp|P81265 & $83,694.6$ & 7.07 & 13 & 378 & 100 & 346 & 100 \\
\hline 13 & $\begin{array}{c}\text { Polymeric } \\
\text { immunoglobulin } \\
\text { receptor }\end{array}$ & PIGR & Bos taurus & sp|P81265 & $83,694.6$ & 7.07 & 15 & 206 & 100 & 162 & 100 \\
\hline 14 & $\begin{array}{l}\text { Immunoglobulin heavy } \\
\text { constant mu }\end{array}$ & IGHM & Ovis aries & $\operatorname{tr|W5NXW9}$ & $50,606.7$ & 5.44 & 13 & 736 & 100 & 671 & 100 \\
\hline 15 & $\begin{array}{l}\text { Immunoglobulin heavy } \\
\text { constant mu }\end{array}$ & IGHM & Ovis aries & $\operatorname{tr|W5NXW9}$ & $50,606.7$ & 5.44 & 12 & 521 & 100 & 468 & 100 \\
\hline 16 & $\begin{array}{l}\text { Immunoglobulin heavy } \\
\text { constant mu }\end{array}$ & IGHM & Ovis aries & $\operatorname{tr} \mid$ W5NXW9 & $50,606.7$ & 5.44 & 14 & 544 & 100 & 475 & 100 \\
\hline
\end{tabular}


Table 2. Cont

\begin{tabular}{|c|c|c|c|c|c|c|c|c|c|c|c|}
\hline Spot Number & Protein Name & Abbreviation & Organism & Accession No. & Protein MW & Protein PI & Pep. Count & Protein Score & Protein Score C. I. \% & Total Ion & Total Ion C. I. \% \\
\hline 17 & $\begin{array}{l}\text { Immunoglobulin heavy } \\
\text { constant mu }\end{array}$ & IGHM & Ovis aries & $\operatorname{tr|W5NXW9}$ & $50,606.7$ & 5.44 & 11 & 467 & 100 & 423 & 100 \\
\hline 18 & $\begin{array}{l}\text { Immunoglobulin heavy } \\
\text { constant mu }\end{array}$ & IGHM & Ovis aries & tr|W5NXW9 & $50,606.7$ & 5.44 & 14 & 550 & 100 & 481 & 100 \\
\hline 19 & Airway lactoperoxidase & ALPO & Ovis aries & $\operatorname{tr|} \mid \mathrm{QMZY2}$ & $81,348.5$ & 8.95 & 20 & 237 & 100 & 176 & 100 \\
\hline 20 & Nucleobindin-1 & NUCB1 & Ovis aries & tr|W5PS94 & 53,546 & 5.13 & 18 & 137 & 100 & 68 & 99.9 \\
\hline 21 & Nucleobindin-1 & NUCB1 & Ovis aries & tr|W5PS94 & 53,546 & 5.13 & 18 & 149 & 100 & 76 & 100 \\
\hline 22 & $\begin{array}{c}\text { Vitamin D-binding } \\
\text { protein }\end{array}$ & VTDB & Bos taurus & sp|Q3MHN5 & $54,903.7$ & 5.36 & 8 & 73 & 99.5 & 51 & 99.8 \\
\hline 23 & $\begin{array}{l}\text { Alpha-1-antitrypsin } \\
\text { transcript variant } 1\end{array}$ & A1ATV1 & Ovis aries & $\operatorname{tr} \mid[1 \mathrm{WXR} 3$ & $46,339.8$ & 5.78 & 11 & 105 & 100 & 64 & 99.9 \\
\hline 24 & $\begin{array}{l}\text { Vitamin D-binding } \\
\text { protein }\end{array}$ & VDBP & Bos taurus & sp|Q3MHN5 & $54,903.7$ & 5.36 & 10 & 174 & 100 & 139 & 100 \\
\hline 25 & $\begin{array}{c}\text { Guanine } \\
\text { nucleotide-binding } \\
\text { protein subunit gamma }\end{array}$ & GNG5 & Ovis aries & $\operatorname{tr} \mid W 5 P W W 2$ & 7427.9 & 9.9 & 3 & 24 & 0 & & \\
\hline 26 & Vimentin & VIM & $\begin{array}{c}\text { Macaca } \\
\text { fascicularis }\end{array}$ & splQ4R4X4 & $53,733.1$ & 5.06 & 17 & 58 & 83.3 & & \\
\hline 27 & $\begin{array}{c}\text { Dual specificity } \\
\text { phosphatase }\end{array}$ & DUPD & Gallus gallus & sp|P0C597 & $24,535.1$ & 5.69 & 6 & 35 & 0 & & \\
\hline 28 & Keratin 10 & KRT10 & Ovis aries & $\operatorname{tr|W5Q160}$ & $57,476.7$ & 5.4 & 12 & 197 & 100 & 158 & 100 \\
\hline 29 & Keratin 10 & KRT10 & Ovis aries & $\operatorname{tr|W5Q160}$ & $57,476.7$ & 5.4 & 10 & 103 & 100 & 77 & 100 \\
\hline 30 & Actin gamma 1 & ACTG1 & Ovis aries & $\operatorname{tr|W5QAX3}$ & 42,292 & 5.31 & 23 & 775 & 100 & 613 & 100 \\
\hline 31 & Actin gamma 1 & ACTG1 & Ovis aries & $\operatorname{tr|W5QAX3}$ & 42,292 & 5.31 & 17 & 521 & 100 & 413 & 100 \\
\hline 32 & Complement $\mathrm{C} 3$ & $\mathrm{C} 3$ & Bos taurus & sp|Q2UVX4 & $188,674.8$ & 6.41 & 19 & 608 & 100 & 588 & 100 \\
\hline 33 & Keratin 10 & KRT10 & Homo sapiens & $\mathrm{sp|P13645}$ & $59,019.8$ & 5.13 & 13 & 114 & 100 & 73 & 99.9 \\
\hline 34 & $\begin{array}{l}\text { G protein-regulated } \\
\text { inducer of neurite } \\
\text { outgrowth } 1\end{array}$ & GPRININ1 & Ovis aries & $\operatorname{tr} \mid$ W5PH95 & $51,169.7$ & 6.19 & 7 & 83 & 99.9 & 61 & 99.9 \\
\hline 35 & $\begin{array}{l}\text { G protein-regulated } \\
\text { inducer of neurite } \\
\text { outgrowth } 1\end{array}$ & GPRININ1 & Ovis aries & $\operatorname{tr} \mid$ W5PH95 & $51,169.7$ & 6.19 & 5 & 70 & 99.7 & 55 & 99.9 \\
\hline 36 & Clusterin & CLU & Ovis aries & tr|W5PZI1 & $51,554.4$ & 5.77 & 14 & 466 & 100 & 401 & 100 \\
\hline 37 & Alpha s1 casein variant & CSN1S1 & Ovis aries & $\operatorname{tr|D3TU01}$ & 23,469 & 5.64 & 10 & 511 & 100 & 454 & 100 \\
\hline 38 & Alpha s1 casein variant & CSN1S1 & Ovis aries & $\operatorname{tr|D3TU01}$ & 23,469 & 5.64 & 13 & 252 & 100 & 166 & 100 \\
\hline
\end{tabular}


Table 2. Cont.

\begin{tabular}{|c|c|c|c|c|c|c|c|c|c|c|c|}
\hline Spot Number & Protein Name & Abbreviation & Organism & Accession No. & Protein MW & Protein PI & Pep. Count & Protein Score & Protein Score C. I. \% & Total Ion & Total Ion C. I. \% \\
\hline 39 & Alpha s2 casein variant & CSN1S2 & Ovis aries & $\operatorname{tr|D3TU01}$ & 23,469 & 5.13 & 15 & 323 & 100 & 271 & 100 \\
\hline 40 & $\begin{array}{c}\text { Kappa casein } \\
\text { (Fragment) }\end{array}$ & CSN3 & Ovis aries & $\operatorname{tr|} \mid \mathrm{A} 0 \mathrm{~A} 059 \mathrm{~T} 9 \mathrm{~V} 6$ & 18,149 & 5.77 & 1 & 44 & 0 & 40 & 99.6 \\
\hline 41 & Kappa-casein & CSN3 & Ovis aries & $\operatorname{tr} \mid \mathrm{A} 0 \mathrm{~A} 059 \mathrm{~T} 9 \mathrm{~N} 6$ & $21,595.9$ & 5.78 & 6 & 272 & 100 & 243 & 100 \\
\hline 42 & Keratin 10 & KRT10 & Ovis aries & $\operatorname{tr|W5Q160}$ & $57,476.7$ & 5.4 & 11 & 251 & 100 & 220 & 100 \\
\hline 43 & $\begin{array}{l}\text { Glycosylation-dependent } \\
\text { cell adhesion molecule } 1\end{array}$ & GLYCAM1 & Ovis aries & $\operatorname{tr}|\mathrm{W} 5 \mathrm{Q} 3 \mathrm{I} 2|$ & 17,117 & 5.41 & 4 & 127 & 100 & 109 & 100 \\
\hline 44 & $\begin{array}{l}\text { Kinesin family } \\
\text { member 20B }\end{array}$ & KIF20B & Ovis aries & $\operatorname{tr} \mid \mathrm{W} 5 \mathrm{Q} 1 \mathrm{Q} 1$ & $211,015.5$ & 5.45 & 39 & 66 & 99.2 & & \\
\hline 45 & Kappa-casein & CSN3 & Ovis aries & $\operatorname{tr|A0A059T9V6~}$ & $21,595.9$ & 5.78 & 4 & 75 & 99.8 & 55 & 99.9 \\
\hline 46 & Kappa-casein & CSN3 & Ovis aries & $\operatorname{tr|A0A059T9V6~}$ & $21,595.9$ & 5.78 & 4 & 156 & 100 & 141 & 100 \\
\hline 47 & Kappa-casein & CSN3 & Ovis aries & $\operatorname{tr|}$ A0A059T9V6 & $21,595.9$ & 5.78 & 4 & 92 & 99.9 & 73 & 100 \\
\hline 48 & Kappa-casein & CSN3 & Ovis aries & $\operatorname{tr|A0A059T9V6~}$ & $21,595.9$ & 5.78 & 5 & 152 & 100 & 131 & 100 \\
\hline 49 & Kappa-casein & CSN3 & Ovis aries & tr|A0A059T9V6 & $21,595.9$ & 5.78 & 4 & 135 & 100 & 117 & 100 \\
\hline 50 & Uncharacterized protein & & Ovis aries & $\operatorname{tr} \mid \mathrm{W} 5 \mathrm{NPX} 0$ & $22,587.1$ & 5.29 & 4 & 20 & 0 & & \\
\hline 51 & Serum albumin & ALB & Ovis aries & tr|W5PWE9 & $71,372.1$ & 5.79 & 31 & 1020 & 100 & 822 & 100 \\
\hline 52 & $\begin{array}{l}\text { Immunoglobulin alpha } \\
\text { heavy chain }\end{array}$ & IGHC & Ovis aries & tr|W5PH95 & $51,169.7$ & 6.19 & 5 & 170 & 100 & 148 & 100 \\
\hline
\end{tabular}




\subsection{GO Annotation and KEGG Pathway Enrichment Analysis of DEPS}

GO annotation was used for functional analysis of the DEPs. A total of 382, 73, and 80 items were enriched in the categories of biological process, cell component, and molecular function, respectively. Proteins assigned to each category are presented in Figure 2. In the biological process category, most of the proteins were assigned to localization, the single-organism process, and the cellular process, followed by biological regulation and the metabolic process. The proteins were also assigned to immune-related processes: the immune system process and response to stimulus. The most predominant cellular components identified were in the extracellular region, whereas other proteins were mainly located in the cell, organelle, membrane, and macromolecular complex. In the molecular function analysis, the binding activity accounted for a large proportion of the proteins, which included lipid, sulfate, isoprenoid, retinol, and vitamin binding. This means that whey proteins also have an important role in energy supplement for lambs. Binding activity was also reported as the most common molecular function in diverse animal species [8]. In addition, a small number of DEPs was annotated as belonging to other functional categories such as the molecular function regulator, transporter activity, catalytic activity, etc. Anagnostopoulos et al. characterized the whey proteome of three different pure-breed Greek sheep, and the GO results revealed that the biological function of the whey proteins was highly similar between the breeds [44]. Comparing the GO annotation results in the present study with the Greek breeds, variation in the biological function of whey protein was present but minimal.

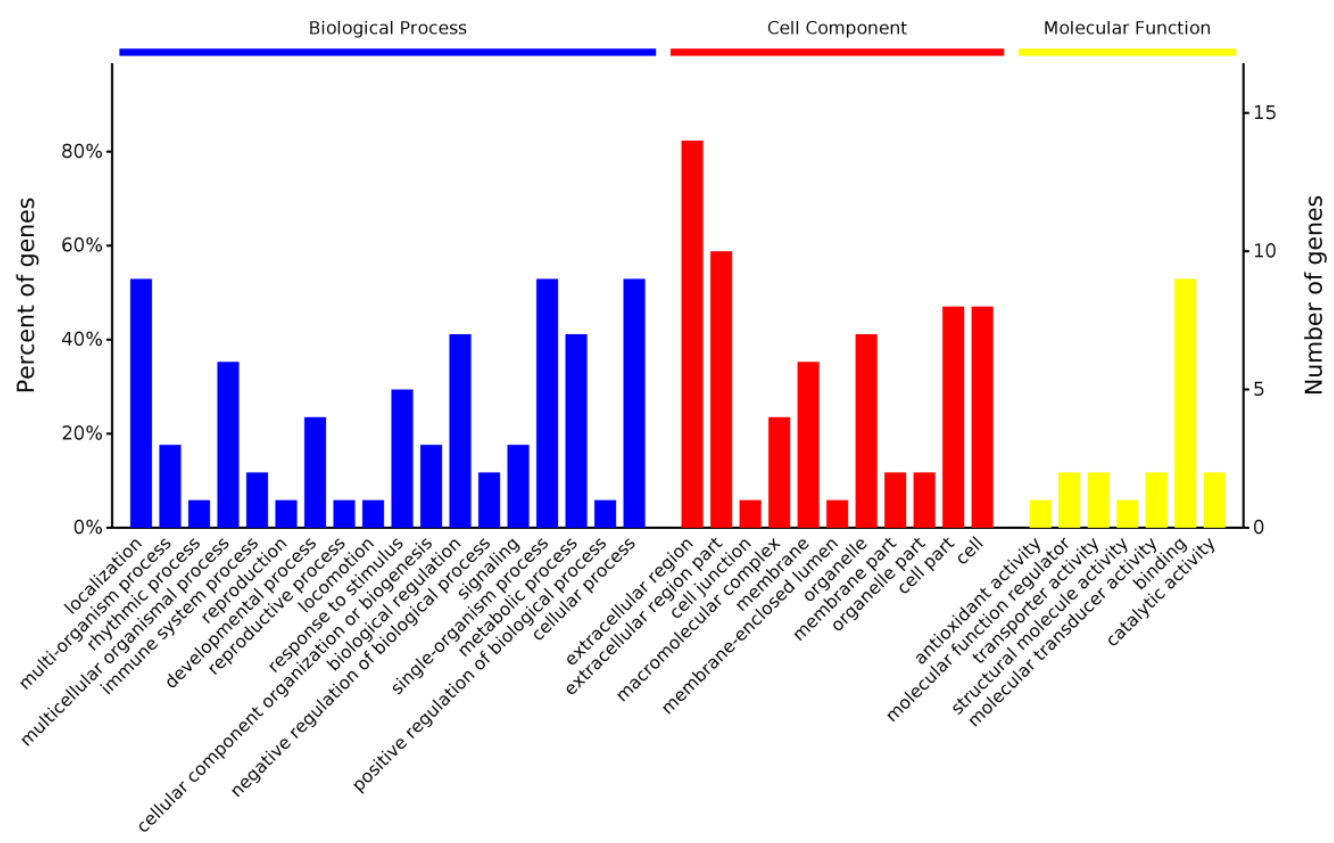

Figure 2. Classification of differentially expressed whey proteins based on gene ontology annotation.

The 24 characterized differentially expressed whey proteins were further analyzed based on the KEGG pathways. Nine pathways were significantly enriched (Table 3). According to the results, these DEPs participate primarily in the Hippo signaling pathway. The Hippo signaling pathway regulates diverse physiological processes involved in development, homeostasis, regeneration, and disease [45]. The DEPs were also found to participate in other vital pathways, such as the complement and coagulation cascades. This pathway plays crucial roles in protecting the host against pathogens and other invaders, which is critical for the newborn's health [46]. These results provide new information on how whey proteins execute biological functions in lambs' immunity and development. 
Table 3. Kyoto Encyclopedia of Genes and Genomes (KEGG) pathway analysis of whey DEPs.

\begin{tabular}{|c|c|c|c|}
\hline Pathway Name & Pathway ID & Count & $p$ Value \\
\hline Hippo signaling pathway* & oas04390 & 2 & $2.18 \times 10^{-3}$ \\
\hline Arrhythmogenic right ventricular cardiomyopathy (ARVC) * & oas05412 & 1 & $3.46 \times 10^{-2}$ \\
\hline Adherens junction * & oas 04520 & 1 & $3.55 \times 10^{-2}$ \\
\hline Viral myocarditis * & oas 05416 & 1 & $3.89 \times 10^{-2}$ \\
\hline Hypertrophic cardiomyopathy (HCM)* & oas05410 & 1 & $3.94 \times 10^{-2}$ \\
\hline Bacterial invasion of epithelial cells * & oas05100 & 1 & $3.94 \times 10^{-2}$ \\
\hline Dilated cardiomyopathy * & oas05414 & 1 & $4.23 \times 10^{-2}$ \\
\hline Salmonella infection * & oas05132 & 1 & $4.38 \times 10^{-2}$ \\
\hline Complement and coagulation cascades * & oas04610 & 1 & $4.76 \times 10^{-2}$ \\
\hline Thyroid hormone signaling pathway & oas04919 & 1 & $5.58 \times 10^{-2}$ \\
\hline Leukocyte transendothelial migration & oas04670 & 1 & $5.92 \times 10^{-2}$ \\
\hline Platelet activation & oas04611 & 1 & $6.11 \times 10^{-2}$ \\
\hline Tight junction & oas 04530 & 1 & $6.73 \times 10^{-2}$ \\
\hline Apoptosis & oas04210 & 1 & $7.20 \times 10^{-2}$ \\
\hline Oxytocin signaling pathway & oas04921 & 1 & $7.72 \times 10^{-2}$ \\
\hline Cell adhesion molecules (CAMs) & oas04514 & 1 & $7.91 \times 10^{-2}$ \\
\hline Influenza A & oas05164 & 1 & $8.98 \times 10^{-2}$ \\
\hline Phagosome & oas04145 & 1 & $9.12 \times 10^{-2}$ \\
\hline Proteoglycans in cancer & oas05205 & 1 & $1.01 \times 10^{-1}$ \\
\hline Rap1 signaling pathway & oas04015 & 1 & $1.02 \times 10^{-1}$ \\
\hline Focal adhesion & oas 04510 & 1 & $1.02 \times 10^{-1}$ \\
\hline Regulation of actin cytoskeleton & oas 04810 & 1 & $1.04 \times 10^{-1}$ \\
\hline
\end{tabular}

* indicates significant enrichment pathway $(p<0.05)$.

\section{Conclusions}

This is the first time to deeply explore the dynamic changes in sheep whey proteins during the first $56 \mathrm{~d}$ of lactation, and a total of 52 differentially expressed protein spots (DEPS), corresponding to 25 differentially expressed proteins (DEPs), were identified. The protein spots abundance analysis revealed that the proteins are the most abundant at $0 \mathrm{~d}$ after lambing, and then revealed dynamic changes before lamb weaning. According to the GO annotation and KEGG pathway analysis, the DEPs are involved in multiple biological functions, especially in immunity. Our findings add to the understanding of the protein composition of whey and provide a scientific basis for early feeding and weaning of lambs from the perspective of milk proteins. The results of the present study show that weaning at $28 \mathrm{~d}$ after lambing can be considered.

Supplementary Materials: The following are available online at http://www.mdpi.com/2076-2615/10/10/1784/s1.

Author Contributions: F.L. and X.Y. designed and conceived the experiments; X.L. performed the experiment; X.L., X.Y., and X.Z. carried out data processing, analysis, and interpretation; X.Z. and X.Y. were responsible for the writing of the manuscript. All authors have read and agreed to the published version of the manuscript.

Funding: This research was supported by National Key R\&D Program of China (2018YFD0502001), Program for Changjiang Scholars and Innovative Research Team in University (IRT_17R50), China Agriculture Research System (CARS-38).

Conflicts of Interest: The authors declare no conflict of interest.

\section{References}

1. Milani, F.X.; Wendorff, W.L. Goat and sheep milk products in the United States (USA). Small Rumin. Res. 2011, 101, 134-139. [CrossRef]

2. Tacoma, R.; Fields, J.; Ebenstein, D.B.; Lam, Y.W.; Greenwood, S.L. Characterization of the bovine proteome in early-lactation Holstein and Jersey breeds of dairy cows. J. Proteom. 2016, 130, 200-210. [CrossRef] [PubMed]

3. Roncada, P.; Piras, C.; Soggiu, A.; Turk, R.; Urbani, A.; Bonizzi, L. Farm animal milk proteomics. J. Proteom. 2012, 75, 4259-4274. [CrossRef] [PubMed] 
4. Beck, K.L.; Weber, D.; Phinney, B.S.; Smilowitz, J.T.; Hinde, K.; Lönnerdal, B.; Korf, I.; Lemay, D.G. Comparative Proteomics of Human and Macaque Milk Reveals Species-Specific Nutrition during Postnatal Development. J. Proteome Res. 2015, 14, 2143-2157. [CrossRef] [PubMed]

5. Vanderghem, C.; Blecker, C.; Danthine, S.; Deroanne, C.; Haubruge, E.; Guillonneau, F.; Pauw, E.D.; Francis, F. Proteome analysis of the bovine milk fat globule: Enhancement of membrane purification. Int. Dairy J. 2008, 18, 885-893. [CrossRef]

6. Pisanu, S.; Ghisaura, S.; Pagnozzi, D.; Falchi, G.; Biosa, G.; Tanca, A.; Roggio, T.; Uzzau, S.; Addis, M.F. Characterization of sheep milk fat globule proteins by two-dimensional polyacrylamide gel electrophoresis/mass spectrometry and generation of a reference map. Int. Dairy J. 2012, 24, 78-86. [CrossRef]

7. Krissansen, G.W. Emerging health properties of whey proteins and their clinical implications. J. Am. Coll. Nutr. 2007, 26, 713-723. [CrossRef] [PubMed]

8. Yang, Y.; Bu, D.; Zhao, X.; Sun, P.; Wang, J.; Zhou, L. Proteomic analysis of cow, yak, buffalo, goat and camel milk whey proteins: Quantitative differential expression patterns. J. Proteome Res. 2013, 12, 1660-1667. [CrossRef] [PubMed]

9. El-Hatmi, H.; Jrad, Z.; Salhi, I.; Aguibi, A.; Nadri, A.; Khorchani, T. Comparison of composition and whey protein fractions of human, camel, donkey, goat and cow milk. Mljekarstvo 2015, 65, 159-167. [CrossRef]

10. Hernández-Castellano, L.E.; Almeida, A.M.; Ventosa, M.; Coelho, A.V.; Castro, N.; Argüello, A. The effect of colostrum intake on blood plasma proteome profile in newborn lambs: Low abundance proteins. BMC Vet. Res. 2014, 10, 85. [CrossRef]

11. Liao, Y.; Alvarado, R.; Phinney, B.; Lönnerdal, B. Proteomic Characterization of Human Milk Whey Proteins during a Twelve-Month Lactation Period. J. Proteome Res. 2011, 10, 1746-1754. [CrossRef] [PubMed]

12. Le, A.; Barton, L.D.; Sanders, J.T.; Zhang, Q. Exploration of Bovine Milk Proteome in Colostral and Mature Whey Using an Ion-Exchange Approach. J. Proteome Res. 2011, 10, 692-704. [CrossRef] [PubMed]

13. Yang, Y.; Zhao, X.; Yu, S.; Cao, S. Quantitative proteomic analysis of whey proteins in the colostrum and mature milk of yak (Bos grunniens). J. Sci. Food Agric. 2015, 95, 592-597. [CrossRef] [PubMed]

14. Hernández-Castellano, L.E.; Almeida, A.M.; Renaut, J.; Argüello, A.; Castro, N. A proteomics study of colostrum and milk from the two major small ruminant dairy breeds from the Canary Islands: A bovine milk comparison perspective. J. Dairy Res. 2016, 83, 366-374. [CrossRef] [PubMed]

15. Yue, G.H. Reproductive characteristics of Chinese Hu sheep. Anim. Reprod. Sci. 1996, 44, 223-230. [CrossRef]

16. Fragkou, I.A.; Boscos, C.M.; Fthenakis, G.C. Diagnosis of clinical or subclinical mastitis in ewes. Small Rumin. Res. 2014, 118, 86-92. [CrossRef]

17. Qi, Y.X.; Zhao, X.W.; Huang, D.W.; Cai, D.D.; Yang, Y.X.; Cheng, G.L.; Zhao, H.L. Proteomics Study on Preparation of Bovine Whey by Ultracentrifugation and Acid Precipitation. Zhongguo Xu Mu Shou Yi 2019, 46, 2203-2210. [CrossRef]

18. Görg, A.B.G.; Harder, A.; Scheibe, B.; Wildgruber, R.; Weiss, W. Review The current state of two-dimensional electrophoresis with immobilized $\mathrm{pH}$ gradients Proteomics and 2-DE. Electrophoresis 2000, 21, 1037-1053. [CrossRef]

19. Wu, W.Z.; Wang, X.Q.; Wu, G.Y.; Kim, S.W.; Wang, J.J. Differential composition of proteomes in sow colostrum and milk from anterior and posterior mammary glands. J. Anim. Sci. 2010, 88, 2657-2664. [CrossRef]

20. Candiano, G.; Bruschi, M.; Musante, L.; Santucci, L.; Ghiggeri, G.M.; Carnemolla, B.; Orecchia, P.; Zardi, L.; Righetti, P.G. Blue silver: A very sensitive colloidal Coomassie G-250 staining for proteome analysis. Electrophoresis 2004, 25, 1327-1333. [CrossRef]

21. Stefan, G.; Miguel, G.G.J.; Javier, T.; Williams, T.D.; Nagaraj, S.H.; José, N.M.; Montserrat, R.; Manuel, T.; Joaquín, D.; Ana, C. High-throughput functional annotation and data mining with the Blast2GO suite. Nucleic Acids Res. 2008, 36, 3420-3435. [CrossRef]

22. Ashburner, M.; Ball, C.A.; Blake, J.A.; Botstein, D.; Cherry, J.M. Gene ontology: Tool for the unification of biology. Nat. Genet. 2000, 25, 25-29. [CrossRef] [PubMed]

23. Minoru, K.; Susumu, G.; Yoko, S.; Miho, F.; Mao, T. KEGG for integration and interpretation of large-scale molecular data sets. Nucleic Acids Res. 2011, 40, 109-114. [CrossRef]

24. Lorenzo, H.C.; Andre, A.; Noemi, C.; Anastasio, A. The Colostrum Proteome, Ruminant Nutrition and Immunity: A Review. Curr. Protein Pept. Sci. 2014, 15, 64-74. [CrossRef] 
25. Vânia, F.L.; Eduardo, L.S.G.; José, A.B.A.; José, J.F.; Paulo, C.S.; Soares, P.C.; Mendonça, C.L. Proteinogram the whey protein of Santa Ines sheep breed in different stages of lactation. Pesqui. Vet. Bras. 2013, 33, 807-812. [CrossRef]

26. Katsafadou, A.I.; Tsangaris, G.T.; Anagnostopoulos, A.K.; Billinis, C.; Barbagianni, M.S.; Vasileiou, N.G.C.; Spanos, S.A.; Mavrogianni, V.S.; Fthenakis, G.C. Differential quantitative proteomics study of experimental Mannheimia haemolytica mastitis in sheep. J. Proteom. 2019, 205, 103393. [CrossRef]

27. Wang, B.; Timilsena, Y.P.; Blanch, E.; Adhikari, B. Lactoferrin: Structure, function, denaturation and digestion. Crit. Rev. Food Sci. Nutr. 2019, 59, 580-596. [CrossRef]

28. Wu, Y.F.; Ge, W.P.; Liu, K.R.; Song, Y.X.; Zhao, L.L.; Zhang, W.B.; Wang, Y.X.; Liang, X.Z. Analysis of nutritional composition and whey protein composition of sheep milk: A comparison with milk from humans and other mammals. J. Dairy Sci. Technol. 2019, 42, 1-5. [CrossRef]

29. De Serres, F.; Blanco, I. Role of alpha-1 antitrypsin in human health and disease. J. Intern. Med. 2014, 276, 311-335. [CrossRef]

30. Hernandez-Castellano, L.E.; Arguello, A.; Almeida, A.M.; Castro, N.; Bendixen, E. Colostrum protein uptake in neonatal lambs examined by descriptive and quantitative liquid chromatography-tandem mass spectrometry. J. Dairy Sci. 2015, 98, 135-147. [CrossRef]

31. Masuho, I.; Mototani, Y.; Sahara, Y.; Asami, J.; Nakamura, S.; Kozasa, T.; Inoue, T. Dynamic expression patterns of $G$ protein-regulated inducer of neurite outgrowth 1 (GRIN1) and its colocalization with G $\alpha_{0}$ implicate significant roles of Goo-GRIN1 signaling in nervous system. Dev. Dyn. 2010, 237, 2415-2429. [CrossRef] [PubMed]

32. Janssen, B.J.C.; Huizinga, E.G.; Raaijmakers, H.C.A.; Roos, A.; Daha, M.R.; Nilsson-Ekdahl, K.; Nilsson, B.; Gros, P. Structures of complement component C3 provide insights into the function and evolution of immunity. Nature 2005, 437, 505-511. [CrossRef] [PubMed]

33. Garcia-Aranda, M.; Serrano, A.; Redondo, M. Regulation of Clusterin Gene Expression. Curr. Protein Pept. Sci. 2018, 19, 612-622. [CrossRef] [PubMed]

34. Dominguez, R.; Holmes, K.C. Actin Structure and Function. Annu. Rev. Biophys. 2011, 40, 169-186. [CrossRef]

35. Clark, S.; Mora García, M.B. A 100-Year Review: Advances in goat milk research. J. Dairy Sci. 2017, 100, 10026-10044. [CrossRef]

36. Kong, X.H.; Wang, L.; Chao, P.; Zhang, J.; Zhao, X.L.; Li, L. Comparison of polymeric immunoglobulin receptor between fish and mammals. Vet. Immunol. Immunopathol. 2018, 202, 63-69. [CrossRef]

37. Hosono, K.; Noda, S.; Shimizu, A.; Nakanishi, N.; Ohtsubo, M.; Shimizu, N.; Minoshima, S. YPEL5 protein of the YPEL gene family is involved in the cell cycle progression by interacting with two distinct proteins RanBPM and RanBP10. Genomics 2010, 96, 102-111. [CrossRef]

38. Ha, M.; Sabherwal, M.; Duncan, E.; Stevens, S.; Stockwell, P.; McConnell, M.; Bekhit, A.E.; Carne, A. In-Depth Characterization of Sheep (Ovis aries) Milk Whey Proteome and Comparison with Cow (Bos taurus). PLOS ONE 2015, 10, e0139774. [CrossRef]

39. Delanghe, J.R.; Speeckaert, R.; Speeckaert, M.M. Behind the scenes of vitamin D binding protein: More than vitamin D binding. Best Pract. Res. Clin. Endocrinol. Metab. 2015, 29, 773-786. [CrossRef]

40. Bragulla, H.H.; Homberger, D.G. Structure and functions of keratin proteins in simple, stratified, keratinized and cornified epithelia. J. Anat. 2009, 214, 516-559. [CrossRef]

41. Chong, L.; Wang, W.; Liu, T.; Qian, Z.; Wang, G.; Li, F.; Fei, L.; Yue, X.; Li, T. Effect of Early Weaning on the Intestinal Microbiota and Expression of Genes Related to Barrier Function in Lambs. Front. Microbiol. 2018, 9 , 1431. [CrossRef]

42. Ayadi, M.; Such, X.; Ezzehizi, N.; Zouari, M.; Najar, T.; Rad, M.B.M.; Casals, R. Relationship between mammary morphology traits and milk yield of Sicilo-Sarde dairy sheep in Tunisia. Small Rumin. Res. 2011, 96, 41-45. [CrossRef]

43. Ma, Z.; Li, F.; Li, F.; Li, C.; Wang, W.; Tang, D.; Liu, T.; Pan, X. Effect of Early Weaning on Performance and Gastrointestinal Tract Development of Hu lambs. Dongwu Yingyang Xuebao 2015, 27, 1385-1393. [CrossRef]

44. Anagnostopoulos, A.K.; Katsafadou, A.I.; Pierros, V.; Kontopodis, E.; Fthenakis, G.C.; Arsenos, G.; Karkabounas, S.; Tzora, A.; Skoufos, I.; Tsangaris, G. Milk of Greek sheep and goat breeds; characterization by means of proteomics. J. Proteom. 2016, 147, 76-84. [CrossRef] 
45. Pan, D. The Hippo Signaling Pathway in Development and Cancer. Dev. Cell. 2010, 19, 491-505. [CrossRef] 46. Oikonomopoulou, K.; Ricklin, D.; Ward, P.A.; Lambris, J.D. Interactions between coagulation and complement-Their role in inflammation. Semin. Immunopathol. 2012, 34, 151-165. [CrossRef]

(C) 2020 by the authors. Licensee MDPI, Basel, Switzerland. This article is an open access article distributed under the terms and conditions of the Creative Commons Attribution (CC BY) license (http://creativecommons.org/licenses/by/4.0/). 